\title{
The potential of cement stabilized shale quarry dust for possible use as road foundation material

\author{
O. M. Nweke ${ }^{1 *}$ and C. O. Okogbue ${ }^{2}$
}

*Correspondence:
nwaekeoby@yahoo.com
${ }^{1}$ Department of Geology,
Ebonyi State University,
Abakaliki, Nigeria
Full list of author information
is available at the end of the
article

${ }^{*}$ Correspondence: nwaekeoby@yahoo.com Ebonyi State University, Abakaliki, Nigeria

\begin{abstract}
This research investigated the potential of cement stabilized shale quarry dust for possible use as road foundation material. From the results, the shale consists mainly of $\mathrm{SiO}_{2}$ (27.7-60.1\%), $\mathrm{Al}_{2} \mathrm{O}_{3}$ (7.30-17.9\%), $\mathrm{CaO}(3.91-32.3 \%)$ and $\mathrm{LOI}(4.93-18.8 \%)$. The shale quarry dust (SQD) in its natural state had an average liquid limit (LL) as $38 \%$, plasticity index (PI) as $24 \%$ and fines fraction as $14 \%$, which is regarded as poor material according to American Society for Testing and Materials recommendation. The plasticity, compaction, California bearing ratio (CBR) and unconfined compressive strength (UCS) of the SQD were evaluated in its natural state and when mixed with varying percentages of cement. When stabilized with 3\% cement, the strength parameters such as CBR and UCS showed improvement by about 20 and 25\%, respectively, while the swellability indicators; plasticity and shrinkage limit reduced by about 56.2 and $46.6 \%$, respectively, suggesting substantial improvement in the volume stability, strength and stress-strain properties and continued strength gain with time of the cement treated materials. The presence of the carbonate minerals contributed to the improved strength of the SQD for a given cement type and dosage. The beneficial changes in geotechnical properties of SQD when treated with $6 \%$ Portland cement, indicate that treated shale material satisfy most Nigerian specifications for highway fill and embankment, base and sub-base material. Their use, in heavy traffic highway, however, may be handled with caution as the continued high LL may likely imply some swelling on moisture influx.
\end{abstract}

Keywords: Portland cement, Kerbs, Subgrade, Sub-base, Swellability, Umuoghara

\section{Introduction}

Soils are important raw materials for civil engineering work. In most cases, some types of soils that are weak do pose serious challenge to design engineers who might try to change the design, or improve the material or in most cases seek for replacement of the soil with materials of improved properties. Sourcing, evaluation and utilization of alternative materials for replacement of these weak materials are the basic considerations of relevant stakeholders. Indeed, most of the projects in most cases require very large volume of construction materials and their availability should be priority considering the economic cost of moving well known durable materials like gravels from a far distance. As a result of the high cost and the limited availability of certain well known durable construction materials, researches on coal reject, bottom ash, fly ash and a host

(c) The Author(s) 2017. This article is distributed under the terms of the Creative Commons Attribution 4.0 International License (http://creativecommons.org/licenses/by/4.0/), which permits unrestricted use, distribution, and reproduction in any medium, provided you give appropriate credit to the original author(s) and the source, provide a link to the Creative Commons license, and indicate if changes were made. 
of other materials often regarded as waste which are cost effective had led to some of them being recommended for use as pavement materials. Unfortunately, most of these materials in their natural states are unsuitable and do not meet certain specifications required for their use in road foundation as construction materials. In such cases, stabilization is often recommended to improve their geotechnical properties. Authors like Cokca [12], Bandara et al. [6] and Shahiri and Ghasemi [26] had reported on some soil modifiers as substitutes for lime. In most these cases, they reported decrease in dry density and plasticity index and improved stability and shear strength of the treated materials which according to Okagbue and Ochulor [27], are benefits of lime stabilization. Joel and Agbede [17] and Bandara et al. [6] however, recommend cement as economically viable alternative for use in road bases.

The Abakaliki shales due to their hardness and stability have for many years been quarried, processed and utilized as aggregates in Abakaliki (Fig. 1a). The by-product from the quarrying activity of the shale is referred to as shale quarry dust (Fig. 1b) and is locally regarded as 'waste.' Occasionally trucks are seen lifting the waste from the crushing site for improper disposal into the environment. The shale quarry dust is cheap relatively and in abundance at Umuoghara industrial area where commercial and mechanized crushing activities of the rocks are currently being carried out. They are readily available as their rates of production exceed their rate of utilization. A large quantity of the shale dust as at present has remained unutilized and wasting. As a result of high cost and unavailability of certain known durable construction materials, there is need to study the properties of this alternative material regarded as 'waste' by local contractors which in addition to being cost effective and can boost the road life span if further improved through their strength, compressibility and workability for use in flexible pavement design. This research work therefore, uses basic, but standard geotechnical parameters such as grain size distribution, Atterberg limits, compaction, California bearing ratio and unconfined compressive strength to study the properties of the shale quarry dust in their natural state and when stabilized with varying proportion of Portland cement. This will explain the potential of the Portland cement to improve the geotechnical properties of shale quarry dust for possible use in flexible pavement design in road projects.

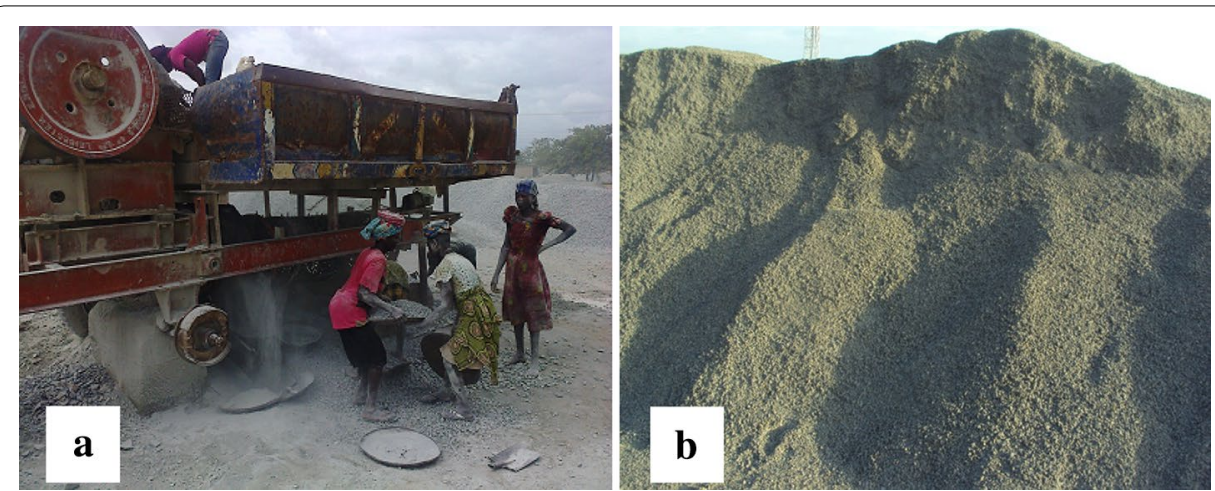

Fig. 1 Photographs of shale quarry dust at Umuoghara industrial sites. a Shale being processed into aggregates with its dust. b Part of shale quarry dust used for the study 


\section{Origin and present use of the shale quarry dust}

The Asu River Group (ARG) which contains shale rock where the studied shale dust was derived, are found within the southern Benue Trough of Nigeria (Fig. 2). The origin and architecture of this basin are presented in details in earlier works such as Murat [20] and Agumanu [2]. The ARG is generally believed to have been deposited by the first marine transgression in the Cretaceous southern Benue Trough, which probably started in the mid-Albian $[2,10]$. The ARG sediments are the oldest Cretaceous sediments which lie unconformably on the Precambrian basement complex. The ARG comprises mainly of sandy shales, with thin limestones around Abakaliki to dark grey-black pyritic micaceous shales, with an estimated thickness of about $2500 \mathrm{~m}$ [2]. Previous researches [10, 21] have it that the southern Benue rifts were filled by Pre-Santonian sedimentary rocks which had undergone regional metamorphism. According to Cratchley and Jones [13], the indurations of the calcareous shales in the area were attributed to the baking effect due to igneous intrusions associated with the shales. Obiora and Charan [21] had extensively studied the occurrence and mineralogy of the shales and reported that they are made up of illite, kaolinite, montmorillonite and vermiculite minerals in descending order of abundance, in addition to non-clay minerals such as quartz and calcite.

The shale rocks are highly indurated and are usually crushed, processed and used as construction materials. Their uses are being based on their hardness and stability as they often behave like hard rocks in civil engineering projects. About 15,000 metric tonnes of crushed aggregates are produced on daily basis. Some local contractors on the other hand use the shale quarry dust, often regarded as waste for moulding road kerbs and blocks. Its utilization is mostly due to their cheap availability. Despite these uses of the materials, the rates of utilization of the materials still lag behind its rate of production. A

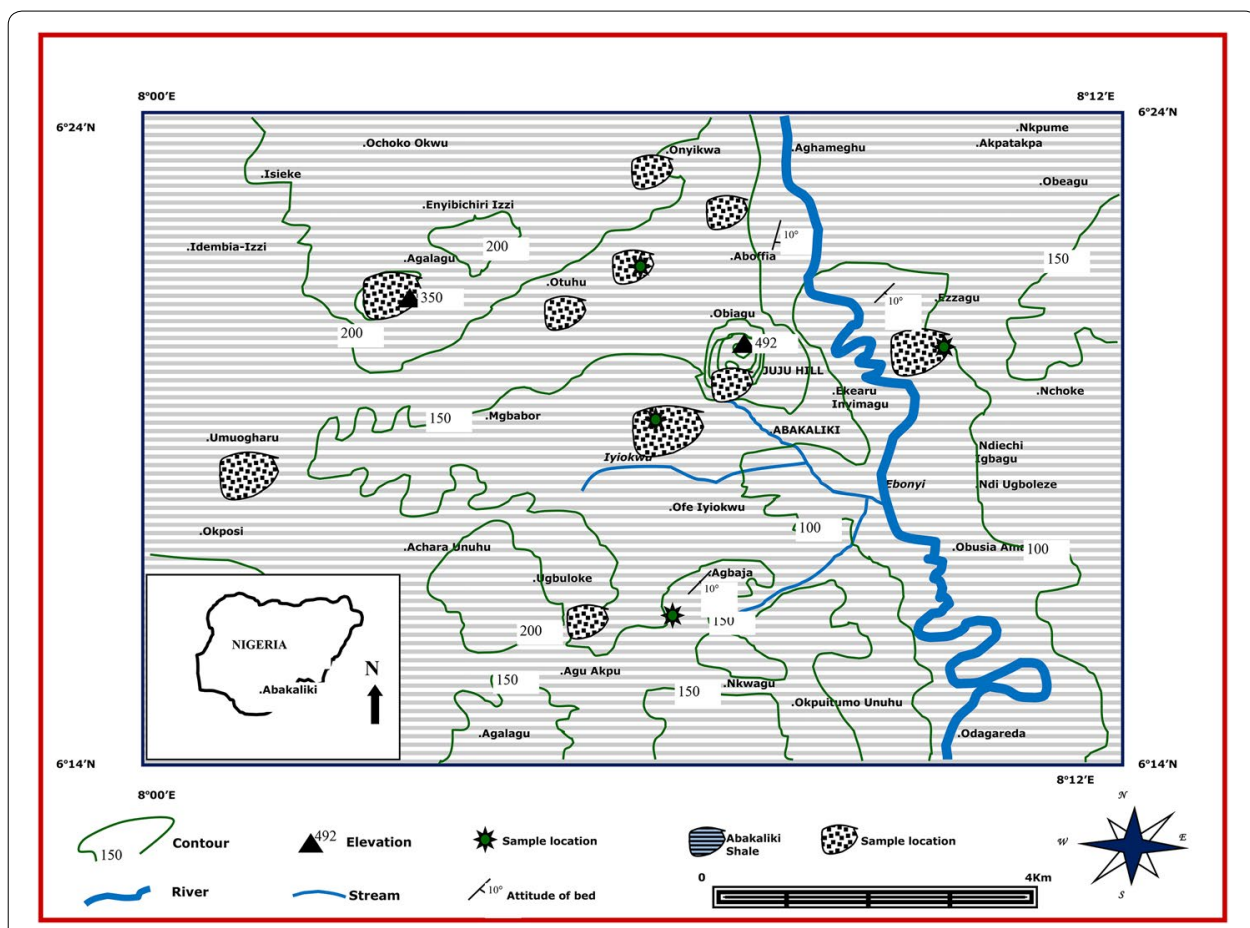

Fig. 2 Geological Map of Abakaliki Metropolis showing sample locations 
large quantity of the shale dust as at present has remained unutilized, which have therefore prompted further studies to exploit other economic value of this material to avoid being considered environmental waste.

\section{Research procedure}

The shale quarry dusts (SQD) were collected from some active quarry sites and Umuoghara industrial sites (Fig. 2). Both shale samples and Portland cement were packaged and transported to the laboratory at National Steel Raw Materials Exploration Agency, Kaduna Nigeria where the samples were subjected to laboratory tests. The SQD collected for the grain size distribution tests in its natural state were air-dried, crushed and passed through the $3 / 4$ in. (19.05 $\mathrm{mm}$ ) mesh of the British standard (BS) test sieves. Laboratory tests that were performed on the shale dust samples included X-ray fluorescence (XRF), grain size distribution, Atterberg limits, compaction, specific gravity, California bearing ratio (CBR) and unconfined compressive strength (UCS) tests. The XRF test followed the procedure described by Jenkens and Synder [16] while the geotechnical tests were generally performed in accordance with BS 1377 [11].

The laboratory analyses were further performed on the mixtures of the Portland cement (PC) with the shale quarry dust (SQD). Measured quantities by weight of dry shale rock dusts with varying percentages $(0,3,6$ and $9 \%)$ of cement were mixed manually in a sample tray for various geotechnical tests. Compaction tests were carried out on both the untreated and treated samples. The compaction tests standard used was both BS and modified American Association of Highway Transportation Officials (AASTHO). CBR type of mould was used for the test and each of the samples was tested 8 times. The conditions of the samples were both soaked and unsoaked conditions. In each case the soaking usually lasted overnight in water filled bathtub. The UCS test was also performed on both untreated and treated samples using British standard. The CBR tests were also performed on both untreated and cement treated materials for both soaked, which lasted for $24 \mathrm{~h}$ and unsoaked conditions. Each of the cement treated SQD was cured naturally for 28 days under laboratory conditions and CBR measurements taken at $7,14,21$ and 28 days respectively to determine the trend of the bearing capacity with time.

\section{Results and discussion}

\section{Geochemical composition and index properties of the shale}

The results of chemical composition of the studied SQD as presented in Table 1 indicate that the $\mathrm{SiO}_{2}$ ranged from 20.7 to $60.1 \%, \mathrm{Al}_{2} \mathrm{O}_{3}$ from 7.30 to $17.9 \%, \mathrm{Fe}_{2} \mathrm{O}_{3}$ from 1.05 to $12.1 \%, \mathrm{CaO}$ from 3.91 to $32.3 \%$ and LOI (loss on ignition) from 4.93 to $18.8 \%$. According to Sayat and Gonconglu [25], LOI gives a good indicator of deleterious substances most especially carbonates which considering the high LOI values recorded, strongly suggest the presence of secondary volatile and carbonate phase. The SQD consists mainly of high proportions of $\mathrm{SiO}_{2}, \mathrm{Al}_{2} \mathrm{O}_{3}, \mathrm{CaO}$ and LOI. The presence of the carbonate minerals as reflected in the works of Obiora and Charan [21] would increase the strength of the shale quarry dust for a given cement type and dosage. Portland cement, however, must contain in proper form the proportions of lime, silica, alumina and iron oxide. Their 
Table 1 Geochemical properties of the untreated shale quarry dust and Portland cement

\begin{tabular}{|c|c|c|c|}
\hline \multirow[t]{2}{*}{ Properties } & \multicolumn{2}{|c|}{ Shale quarry dust ${ }^{a}$} & \multirow{2}{*}{$\begin{array}{l}\text { Portland cement }{ }^{\text {b }} \\
\text { Ave. }\end{array}$} \\
\hline & Range & Ave. & \\
\hline \multicolumn{4}{|l|}{ Chemical properties } \\
\hline Silica oxide, $\mathrm{SiO}_{2}(\%)$ & $20.7-60.1$ & 45.5 & 20.7 \\
\hline Iron oxide, $\mathrm{Fe}_{2} \mathrm{O}_{3}(\%)$ & $1.05-12.1$ & 4.81 & 2.4 \\
\hline Alumina oxide, $\mathrm{Al}_{2} \mathrm{O}_{3}(\%)$ & $7.30-17.9$ & 11.9 & 6.0 \\
\hline $\mathrm{SiO}_{2}+\mathrm{Fe}_{2} \mathrm{O}_{3}+\mathrm{Al}_{2} \mathrm{O}_{3}(\%)$ & & 62.2 & 29.1 \\
\hline Calcium oxide, $\mathrm{CaO}(\%)$ & $3.91-32.3$ & 18.5 & 63.6 \\
\hline Magnesium oxide, MgO (\%) & $0.06-2.01$ & 0.77 & 2.4 \\
\hline Sodium oxide, $\mathrm{Na}_{2} \mathrm{O}(\%)$ & $0.03-1.61$ & 0.65 & 0.1 \\
\hline Sulfur trioxide, $\mathrm{SO}_{3}(\%)$ & $0.04-1.36$ & 0.54 & 1.4 \\
\hline Potassium oxide, $\mathrm{K}_{2} \mathrm{O}(\%)$ & $2.28-8.05$ & 4.40 & 0.7 \\
\hline Loss on ignition LOI (\%) & $4.93-18.8$ & 16.1 & 1.2 \\
\hline
\end{tabular}

a This study

b Adapted from Joel and Agbede [17]

geochemical composition, according to Joel and Agbede [17] as presented in Table 2 has $\mathrm{CaO}$ as $63.6 \%, \mathrm{SiO}_{2}$ as $20.7 \%$ and $\mathrm{Al}_{2} \mathrm{O}_{3}$ as $6.0 \%$.

The results of the grain size distribution of the studied SQD are presented in Table 2. From the ten samples analyzed, the average of gravel fraction $(>4.75 \mathrm{~mm})$ is $30 \%$, sand fraction $(0.075-4.75 \mathrm{~mm})$ is $56 \%$ and the fines fraction $(<0.075 \mathrm{~mm})$ is $14 \%$ while the linear shrinkage (LS) is $12.4 \%$. The results indicate that the shale samples are characterized by high proportions of gravel sand-sized particles. According to Bandara et al. [6], most economically stabilized soil can be produced by using untreated material which contains $5-35 \%$ of particles finer than $0.075 \mathrm{~mm}$ in size as noted in the studied shale.

Table 2 Index properties of the untreated shale material

\begin{tabular}{lll}
\hline Property & Untreated shale material & \\
\cline { 3 - 3 } & Range & Mean $^{\mathbf{a}}$ \\
\hline Grain size distribution (\%) & & 14 \\
Fines, $<0.075 \mathrm{~mm}$ & $6-17$ & 56 \\
Sand, $0.075-4.75 \mathrm{~mm}$ & $34-61$ & 30 \\
Gravel, $>4.75 \mathrm{~mm}$ & $24-36$ & 2.62 \\
Specific gravity & $2.45-2.79$ & 38 \\
Atterberg limit & & 24 \\
Liquid limit (\%) & $34-40$ & 14 \\
Plastic limit (\%) & $18-28$ & 12.4 \\
Plasticity index (\%) & $10-18$ & 1.79 \\
Linear shrinkage (\%) & $8.5-15.8$ & 16.0 \\
Compaction (BS) & & 10.0 \\
Maximum dry density (mg/m $\left.{ }^{3}\right)$ & $1.76-1.98$ & 12.0 \\
Optimum moisture content (\%) & $16.0-18.9$ & 88.0 \\
California bearing ratio & & $10-14.9$ \\
Unsoaked at British standard & $9-14.2$ & \\
Soaked at British standard & $67-89$ & \\
Unconfined compressive strength $\left(\mathrm{kN} / \mathrm{m}^{2}\right)$ & &
\end{tabular}

${ }^{a}$ Average values of 15 samples of shale quarry dust 


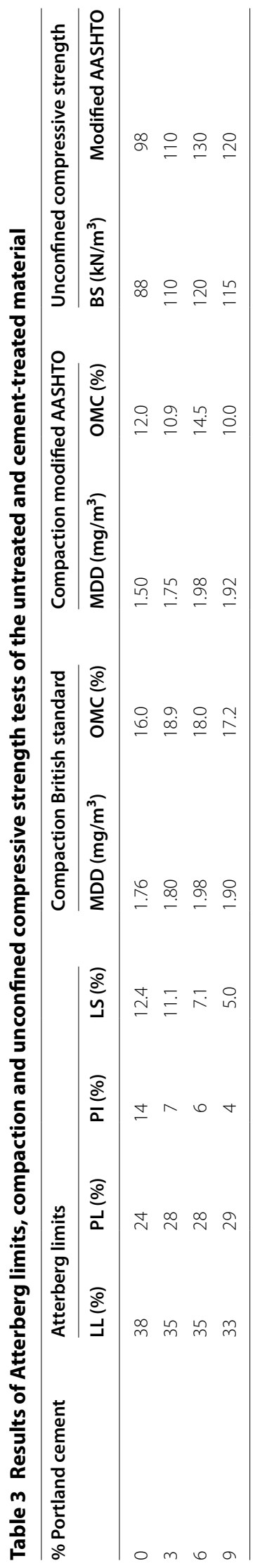


The specific gravity (SG) as presented in Table 2 has an average value of is 2.62 . The SG might be a reflection of the heavy oxides ( $\mathrm{Fe}+\mathrm{Mg}$ content) with an average value of 5.58\% present in the rock. Aghamelu and Okogbue [3] reported that the SGs are reflections of the densities of the materials in each sample, in exclusive of the permeable voids they may contain which thus imply that high SG results in high density. This is likely the case with the studied shale rock. American Society for Testing and Materials [4] indicates that soil with liquid limit (LL) > 10, plasticity index (PI) > 10 and greater than $35 \%$ finer than $75 \mu \mathrm{m}$ may be rated as very poor material when considered for potential use as sub-base, base course and sub-grade materials. The SQD has an average LL as $38 \%$, PI as $24 \%$ and fines fraction of $14 \%$ which according ASTM [4] recommendation, can be regarded as poor material hence that need for improvement of its geotechnical properties to serve well as sub-base, base course and sub-grade materials.

\section{Atterberg limit of cement stabilized shale quarry dust}

The results of the Atterberg limit tests on untreated and cement treated shale materials are presented in Table 3 and Fig. 3. From the results, the LL, PI and LS of cement treated shale materials at 3\% PC dropped from 38 to 35,14 to 7 and 12.4 to $11.1 \%$, respectively. At $6 \%$ cement, the PI and LS of the cement treated shale material further dropped significantly to 6 and $7.1 \%$, representing about 56.2 and 46.6\%, respectively. According to United States Bureau of Reclamation [5] showed that the addition of $4 \%$ lime can reduce the PI of a clay soil significantly from 47 to $12 \%$. Bell [7] and Okagbue and Ochulor [23] had reported that flocculation of clay, cation exchange, agglomeration and pozzolanic reactions are a number of mechanisms that may be responsible for beneficial changes in engineering properties of soil when treated with lime and other additives. In this study, cation exchange and flocculation reactions may have resulted in the suppression of the plasticity of the cement stabilized shale dust at 3\% cement. This is believed to have ultimately led to the formation of coarser particles, which may have contributed significantly to the decrease in plasticity thereby preventing, to some extent, the swellability of the cement treated shale material on moisture influx. This largely agrees with the works of other researchers such as Muntohar [19], Parsons and Kneebone [24] and Afolagboye and Talabi [1]. On the basis of Atterberg limits, the reductions in the PI suggest an improvement in the engineering properties of the shale quarry dust.

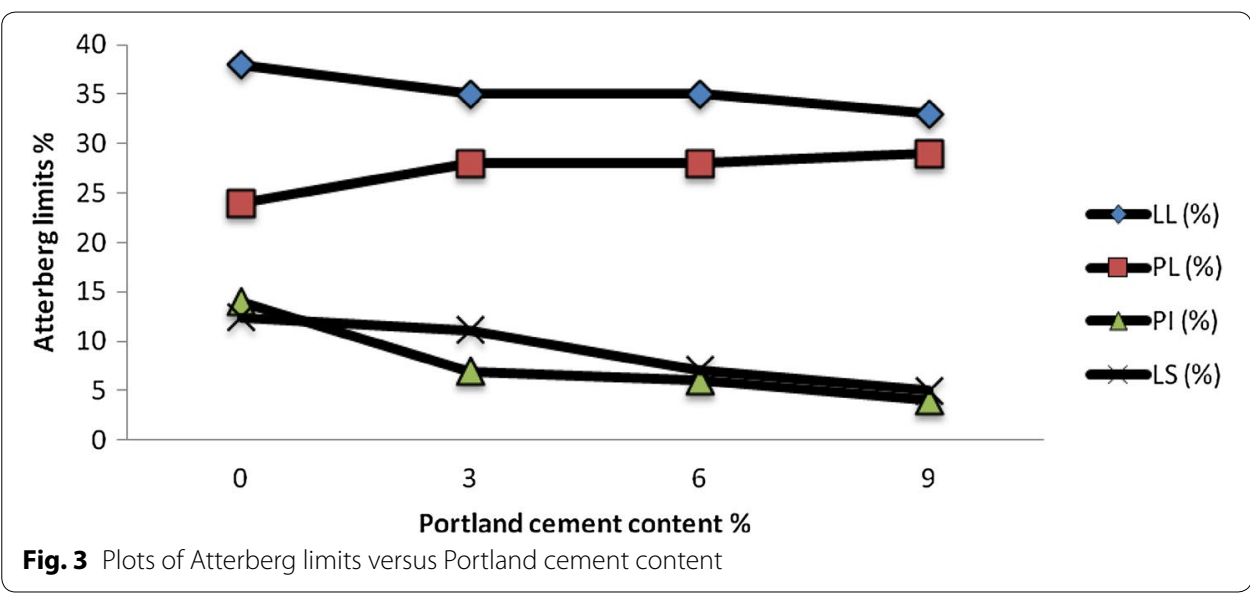




\section{Compaction of cement stabilized shale quarry dust}

The compaction characteristics of the cement treated materials are presented in Table 3. With BS standard, when the SQD was treated with 3\% Portland cement, both the MDD and OMC increased from 1.76 to $1.80 \mathrm{mg} / \mathrm{m}^{3}$ and 16.0 to $18.9 \%$, respectively. With modified AASHTO standard, the MDD increased as the varying percentages of the Portland cement were added to the untreated materials. For instance, at $3 \%$ of PC content, the MDD increased from 1.50 to $1.75 \mathrm{mg} / \mathrm{m}^{3}$ while the OMC decreased from 12.0 to $10.9 \%$. With BS, the fact buttressed by the recorded marginally high OMCs $(\geq 18.0 \%)$ at the addition of $3 \%$ cement, was attributed to the hydration kinetics of the Portland cementshale quarry dust system that would require an amount of water sufficient to achieve proper compaction and hardening. When 9\% PC was mixed with the SQD, the MDD and OMC further increased in a linear manner from with 1.76 to $1.90 \mathrm{mg} / \mathrm{m}^{3}$ (see Fig. 4) and 16.0 to $17.2 \%$, respectively. Nigerian Specification for Road and Bridge Materials recommends that for a material to be used generally as general fills and embankment material, it should possess MDD $>0.047 \mathrm{mg} / \mathrm{m}^{3}$ and $\mathrm{OMC}<18 \%$.

According to Bell [8], depending on the type of soil and the properties required, addition of cement can range from 3 to $16 \%$ by dry weight of soil. This is because as the clay content of a soil increases, so does the quantity of cement required. Okagbue [22] observed that the addition of lime or any other stabilizing agent to clayey soils increased the OMC and reduced the MDD for the same compaction effort making the soils to have more friable structure, which is easier to work and compact. However, the agglomeration of the cement particle around the SQD particles resulted in the increase in the size of the fine particles to coarser particles resulting in the formation of semi rigid soil framework. These changes could be attributed to the effects of cation exchange and short-term pozzolanic reactions between the cement and SQD which may have resulted in the flocculation and agglomeration of the cement stabilized shale dust. In cation exchange reaction, when $\mathrm{Ca}(\mathrm{OH})_{2}$ dissolves in water, some $\mathrm{Ca}^{2+}$ and $(\mathrm{OH})^{-}$ions are formed in the solution. As the concentrations of $\mathrm{Ca}^{2+}$ increase, they exchange with other ions producing one valence on the dust particles. The existing $\mathrm{Na}^{+}$and $\mathrm{K}^{+}$would exchange with the $\mathrm{Ca}^{2+}$ and this reaction continues with increasing $\mathrm{CaO}$ and the this reaction, according to $\mathrm{Wu}$ et al. [28], has added property of soil stabilization by calcification. On the basis of this testing, $\mathrm{PC}$ as stabilizing additive is very effective in improving the strength and stressstrain properties of the SQD material.

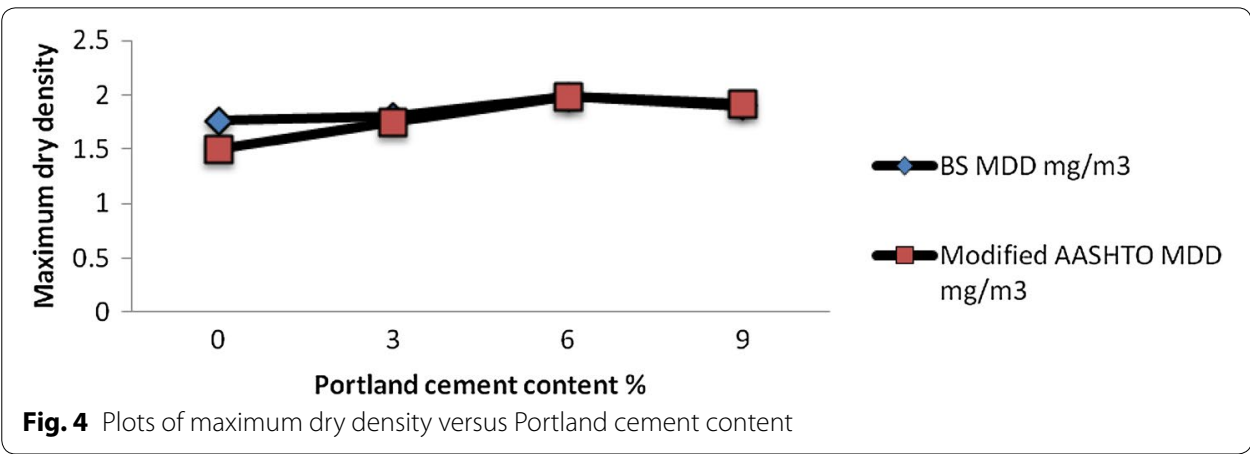




\section{Unconfined compressive strength of cement stabilized shale quarry dust}

The results of the unconfined compressive strength (UCS) of the cement treated materials are presented in Table 3. From the table, the UCS of the cement treated material increased from 88 to 110 and 98 to $110 \mathrm{kN} / \mathrm{m}^{2}$ for both the BS and modified AASHTO standards, respectively, when stabilized with $3 \%$ cement (Fig. 5). At $6 \%$ cement, for both BS and modified AASHTO, the UCS also increased from 88 to 120 and 98 to $130 \mathrm{kN} /$ $\mathrm{m}^{2}$, respectively. According to Bell [8], cement stabilization is controlled by the texture, chemical and clay mineralogy of the soil. Addition of cement up to $6 \%$ was required to stabilize the SQD to further promoted hardening because of the presence of montmorillonite as reported by Obiora and Chara [21], which according to Bell [8], lowers strength development unless enough cement is added to supply the free lime required to promote hardening. The table further showed that the UCS of the cement treated material decreased in both compactive efforts at the addition of $9 \%$ cement.

Cokca [12] and Okagbue [22] have attributed the increase in strength and suppression of high plasticity tendencies of soil during soil stabilization with various natural materials to the development of calcium-silicate-hydrates $(\mathrm{CSH})$ and calcium-aluminate-hydrates $(\mathrm{CAH})$ which are not found in the natural soil except when blended with an additive like lime. Quartz, which according to Obiora and Charan [21] is the predominant non clay mineral of the Abakaliki shale, is chemically inactive, according to Okagbue and Ochulor [23] and therefore does not inhibit strength during stabilization. Kumar and Singh [18] reported that time duration and sufficient water favours greatly the $\mathrm{CSH}$ and $\mathrm{CAH}$ reactions which result eventually to decrease in permeability with the growing reaction product. The SQD with $\mathrm{SiO}_{2}$ and $\mathrm{Al}_{2} \mathrm{O}_{3}$ as the main component, can react with $\mathrm{Ca}(\mathrm{OH})_{2}$ from the $\mathrm{PC}$ and slowly form into $\mathrm{CSH}$ and $\mathrm{CAH}$ with droplets of water, which would result to hardened and coarse material as represented in the two equations. They gave the following equations

$x \mathrm{Ca}(\mathrm{OH})_{2}+\mathrm{SiO}_{2}$ (untreated material) $+(n-1) \mathrm{H}_{2} \mathrm{O}=x \mathrm{CaO} \cdot \mathrm{SiO}_{2} \cdot n \mathrm{H}_{2} \mathrm{O}(\mathrm{CSH})$

$x \mathrm{Ca}(\mathrm{OH})_{2}+\mathrm{Al}_{2} \mathrm{O}_{3}$ (untreated material) $+(n-1) \mathrm{H}_{2} \mathrm{O}=x \mathrm{CaO} \cdot \mathrm{Al}_{2} \mathrm{O}_{3} \cdot n \mathrm{H}_{2} \mathrm{O}(\mathrm{CAH})$

and argued that the products from the equation are complex materials which are insoluble in water. They can become hard as solid material and can bind waste dust like gel

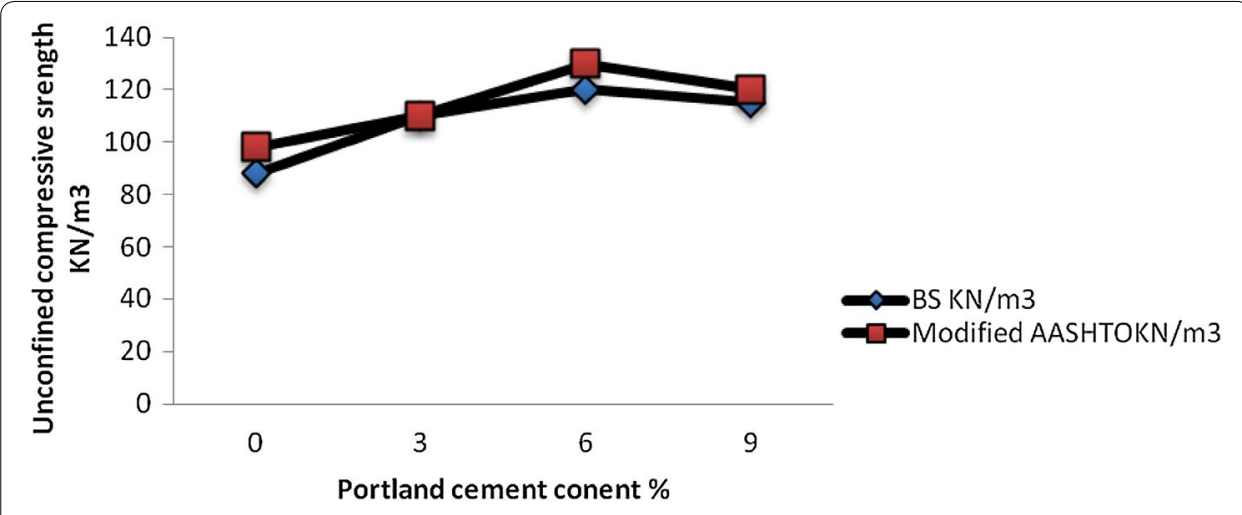

Fig. 5 Plots of unconfined compressive strength versus Portland cement content 
which initially coats and binds lumps of clay together. The gel then crystallizes to form an interlocking structure thereby increasing the strength properties of the SQD. In the present study, there was gradual increase in the UCS in both standards as more of cement was mixed with the SQD up till when $9 \%$ cement was added. According to Bell [8], strength achieved is largely a function of compactive effort, soil texture and, in the case of clay soils, the type of clay minerals present.

When compressive energy was changed from BS to modified AASHTO standards, as $6 \%$ PC was added, the UCS of the treated material increased significantly by about $25 \%$. The higher strength gain recorded with modified AASHTO standard could be attributed to its higher compactive effort. Okagbue and Ochulor [23] attributed the strength gain when the soil stabilized by cement to influence by soil type, clay mineralogy and particle size distribution as well as the interaction of the cement with soil particles and the properties of the cement. The proportion of sand with an average value of $56 \%$ (Table 2), the type and clay mineralogy of the SQD may have contributed to the strength gain upon stabilization. The immediate increase in strength further resulted from flocculationagglomeration reactions which will eventually leads to better workability of the cement treated material.

\section{California bearing ratio of cement stabilized shale quarry dust}

The results of the California bearing ratio (CBR) tests for the soaked and unsoaked samples of untreated material at zero curing and when treated with varying percentages of cement are presented in Table 4. With BS and modified AASHTO standard, at 3\% cement, for unsoaked samples, the CBR increased from 12 to $26 \%$, while for soaked, the CBR increased significantly from 10 to 22 and 12 to 16\%, respectively. For both BS and modified AASHTO standard, upon the addition of cement up to $6 \%$, the CBR values further increased significantly. Maximum values of CBR were achieved when the soils were stabilized with $6 \%$ PC content as over $20 \%$ strength gain were recorded for both BS and modified AASHTO standards after which the CBR values decreased with time for both standards. It is important to note that soaked condition in laboratory analysis usually represents the actual behavior of the fills material under heavy rainfall or flooded conditions. The improved strength and durability is considered long term stabilization that takes place during and after curing due to pozzolanic reactions.

Table 4 Results of CBR and curing days for soaked and unsoaked cement treated material for both BS and modified AASHTO standards

\begin{tabular}{|c|c|c|c|c|c|c|c|c|c|c|c|c|c|c|c|c|}
\hline \multirow[t]{4}{*}{ Day } & \multicolumn{8}{|c|}{ Unsoaked } & \multicolumn{8}{|c|}{ Soaked } \\
\hline & \multirow{2}{*}{\multicolumn{4}{|c|}{$\frac{\text { British standard }}{\text { Portland cement (\%) }}$}} & \multirow{2}{*}{\multicolumn{4}{|c|}{$\frac{\text { Modified AASHTO }}{\text { Portland cement (\%) }}$}} & \multirow{2}{*}{\multicolumn{4}{|c|}{$\frac{\text { British standard }}{\text { Portland cement (\%) }}$}} & \multirow{2}{*}{\multicolumn{4}{|c|}{$\frac{\text { Modified AASHTO }}{\text { Portland cement (\%) }}$}} \\
\hline & & & & & & & & & & & & & & & & \\
\hline & 0 & 3 & 6 & 9 & 0 & 3 & 6 & 9 & 0 & 3 & 6 & 9 & 0 & 3 & 6 & 9 \\
\hline 0 & 10 & 21 & 26 & 26 & 35 & 83 & 85 & 88 & 12 & 16 & 22 & 23 & 12 & 16 & 17 & 22 \\
\hline 7 & 16 & 25 & 26 & 22 & 40 & 86 & 85 & 66 & 16 & 18 & 24 & 17 & 18 & 23 & 30 & 26 \\
\hline 14 & 18 & 26 & 29 & 20 & 44 & 86 & 65 & 55 & 19 & 21 & 20 & 18 & 18 & 25 & 31 & 26 \\
\hline 21 & 22 & 28 & 20 & 18 & 55 & 80 & 50 & 30 & 23 & 26 & 18 & 16 & 26 & 29 & 22 & 20 \\
\hline 28 & 18 & 24 & 20 & 18 & 65 & 78 & 51 & 34 & 18 & 23 & 18 & 18 & 27 & 30 & 20 & 21 \\
\hline
\end{tabular}


Time curing, according to Bell and Coulthard [9], is an important factor influencing the strength of stabilized material as a steady gain in strength for over months is a characteristic. Decrease in the CBR values were recorded after 21 days of curing of cement treated, indicating improved strength, strength gain with time and long term durability of the cement treated material at 3 weeks of curing, after which, the rate of increment in the CBR values reduced gradually. This gradual decrease in the CBR after 21 days of curing could be attributed to breakdown of weak chemical bonds between stabilized constituents which may be as a result that the lime produced was quickly used up within 3 weeks of curing leaving little or no cement for further reaction. In assessment of strength of construction material for pavement design such as base, subbase and subgrade materials, CBR value according to Okagbue and Ochulor [23] is often used as a benchmark. According to Federal Ministry of Works and Housing [14], the CBR recommended values for use as: subgrade, subbase and base course materials are: $\leq 10, \leq 30$ and $\leq 80 \%$, respectively for unsoaked soil. On the basis of the CBR values, the cement treated shale materials improved significantly their bearing capacity thereby satisfying the minimum requirement of United States National Lime Association for lime stabilization.

\section{Suitability of cement stabilized shale quarry dust}

The shale quarry dust in its natural state can be used as highway fill and embankments but is unsuitable when further considered as possible use as subbase and bases materials unless stabilized. The benefits of lime stabilization according to Okagbue and Ochulor [27] include reduction in plasticity and moisture holding capacity, improved stability and shear strength, continued strength gain with time and long term durability over decades of service even under severe environmental conditions. From this research, for modified AASHTO standard, MDD increased with gradual decrease in the OMC even at 3\% Portland cement content. The PC additives substantially improved the volume stability, strength and stress-strain properties and durability of the cement treated materials as they met the benefit of continued strength gain with time. For instance, the Nigerian Specification for Road and Bridge Materials recommends that for a material to be used generally as fills it should possess MDD $>0.047 \mathrm{mg} / \mathrm{m}^{3}, \mathrm{OMC}<18 \%$ and soaked CBR values $>5 \%$. According to Gidigasu [15], both the CBR and UCS are often used to estimate the bearing capacity of highway sub-grade and sub-base soils. Maximum improvements in the bearing capacity and strength of the Portland cement-treated material were achieved when blended with $3 \%$ cement for both standards.

The results of both unstabilized and the Portland cement-stabilized SQD were compared with the Nigerian specifications for highway construction materials in Table 5 . From the table, the cement stabilized material satisfied FMWH [14] requirements for materials used as fill and embankment. The stabilized shale material will also perform satisfactorily well when used as base course materials in exception of its continued high LL and CBR with values (generally $<25 \%$, the acceptable limit). As a sub-base material, the stabilized material would perform well for use in both light and heavy trafficked roads because despite slightly high LL and gradual increase in CBR values with increasing PC, the studied Portland cement-stabilized SQD continued to show continued strength gain and improved the bearing capacity of the studied materials. Although 
Table 5 Properties of cement-treated materials with Nigerian specifications for road and bridge materials

\begin{tabular}{|c|c|c|c|c|c|c|}
\hline \multirow[t]{2}{*}{$\begin{array}{l}\text { Properties } \\
\text { of materials }\end{array}$} & \multirow[t]{2}{*}{$\begin{array}{l}\text { Nigerian } \\
\text { specification }^{a}\end{array}$} & \multirow{2}{*}{$\begin{array}{l}\text { Untreated shale } \\
\text { dust } \\
0 \% \text { PC }\end{array}$} & \multicolumn{3}{|c|}{$\begin{array}{l}\text { Cement stabilized shale } \\
\text { dust }\end{array}$} & \multirow[t]{2}{*}{ Remarks } \\
\hline & & & $3 \% \mathrm{PC}$ & $6 \%$ PC & $9 \% \mathrm{PC}$ & \\
\hline \multicolumn{6}{|l|}{$\begin{array}{l}\text { General filling and } \\
\text { embankment }\end{array}$} & \multirow{7}{*}{$\begin{array}{l}\text { Satisfactory when } \\
\text { used in its natural } \\
\text { state and when } \\
\text { stabilized }\end{array}$} \\
\hline Liquid limit (\%) & $<40$ & 38 & 35 & 35 & 33 & \\
\hline Plasticity index (\%) & $<20$ & 14 & 7 & 6 & 4 & \\
\hline $\operatorname{MDD}\left(\mathrm{mg} / \mathrm{m}^{3}\right)$ & $>0.047$ & 1.76 & 1.80 & 1.98 & 1.90 & \\
\hline OMC (\%) & $<18$ & 16.0 & 18.9 & 18.0 & 17.2 & \\
\hline $\begin{array}{l}\% \text { passing no. } 200 \\
(\%)\end{array}$ & $\leq 35$ & 14 & - & & - & \\
\hline $\begin{array}{l}\text { CBR (24 h soaked) } \\
\text { BS (\%) }\end{array}$ & $\geq 5$ & 12 & 16 & 22 & 23 & \\
\hline \multicolumn{6}{|l|}{ Sub-base course } & \multirow{4}{*}{$\begin{array}{l}\text { Marginally poor } \\
\text { when untreated. } \\
\text { They met other } \\
\text { requirement } \\
\text { when treated } \\
\text { with } 9 \% \text { or more } \\
\text { of Portland } \\
\text { cement except } \\
\text { low CBR values } \\
\text { implies fair stabil- } \\
\text { ity. The materials } \\
\text { should be used } \\
\text { with caution } \\
\text { considering their } \\
\text { wet softening } \\
\text { behavior }\end{array}$} \\
\hline Liquid limit (\%) & $<35$ & 38 & 35 & 35 & 33 & \\
\hline Plasticity index (\%) & $<16$ & 14 & 7 & 6 & 4 & \\
\hline $\begin{array}{l}\text { CBR (24 h soaked) } \\
\text { at West Africa } \\
\text { standard and } \\
\text { OMC (\%) }\end{array}$ & $\geq 25$ & 12 & 16 & 22 & 23 & \\
\hline \multicolumn{6}{|l|}{ Base course } & \multirow{6}{*}{$\begin{array}{l}\text { Poor in its natural } \\
\text { state. Can be } \\
\text { used when sta- } \\
\text { bilized with 3\% } \\
\text { Portland cement } \\
\text { or more but } \\
\text { should be used } \\
\text { with caution with } \\
\text { high LL }\end{array}$} \\
\hline Liquid limit (\%) & $\leq 30$ & 38 & 35 & 35 & 33 & \\
\hline Plasticity index (\%) & $\leq 13$ & 14 & 7 & 6 & 4 & \\
\hline $\begin{array}{l}\% \text { passing sieve } \\
\text { no. } 200(\%)\end{array}$ & $5-15$ & 14 & - & & - & \\
\hline $\begin{array}{l}\text { Unsoaked CBR } \\
\text { at modified } \\
\text { AASHTO and } \\
\text { OMC (\%) }\end{array}$ & $\geq 80$ & 35 & 83 & 85 & 88 & \\
\hline $\begin{array}{l}\text { Unconfined } \\
\text { compressive } \\
\text { strength (kN/ } \\
\mathrm{m}^{2} \text { ) }\end{array}$ & $>103$ & 88.0 & 110 & 120 & 115 & \\
\hline
\end{tabular}

${ }^{a}$ Adapted from Okagbue and Ochulor [23]

these results imply marked improvement in the geotechnical properties of cement stabilized shale quarry dust, there is still slightly high LL which may likely affect the treated material negatively especially when used in construction of heavily trafficked flexible pavements. With increased strength, the use of heavy compaction equipment is recommended in order to achieve increased strength each time the stabilized shale quarry dust is used as pavement materials in road projects. Considering the CBR test results, the stabilized SQD are likely to have fair stability as pavements. However, the use of the studied SQD as flexible pavement material would require water incursion prevention which can be achieved by waterproofing technology. Also, adequate road design and heavy 
compaction are necessary to boost strength and stability of the Portland cement stabilized soils for all purposes.

\section{Conclusions}

The following conclusions can be drawn from this research work.

The shale quarry dusts in their natural state can be used as fill and embankments material but are unsuitable as sub-base and bases materials unless improved. The presence of the carbonate minerals contributed to the improved strength of the SQD for a given cement type and dosage. The stabilization of the SQD with the Portland cement improved the geotechnical properties of the cement stabilized shale material. While the swellability indicators such as plasticity index and linear shrinkage reduced by about 56.2 and $46.6 \%$, respectively, the bearing capacity and strength properties improved by about 25.0 and $37.6 \%$, respectively. The suppression of plasticity made the cement stabilized shale quarry dust more friable, stiff and easily workable. At 3\% Portland cement content and more, the cement treated-stabilized shale dust satisfied Nigerian highway construction specifications for road materials, especially as fills and embankment; for both light and heavy trafficked roads with the reduction in the swellability indicators. The use of heavy compaction equipments resulted in increased strength and stability and is thereby recommended each time the stabilized shale quarry dust is considered for use in road projects. The increased strength and durability is considered long term stabilization that takes place during and after curing. Their use as base course and sub base course, demands caution as although they met other requirements, the relatively high LL (above the recommended limits) may be an indication of expansion and swelling on moisture influx. Compaction tests reveal that although the treatment of the material with 9\% Portland cement would result to increased quality of the cement stabilized shale dust, further addition of the Portland cement greater than $9 \%$ would not be of any economic value as it may possibly influence the quality of the treated material negatively. Interestingly, the trends of results obtained in this research, to some extent satisfy the benefits of lime stabilization recommended by United States National Lime Association.

\section{Authors' contributions}

OMN prepared the introductory part of the work. Did the sampling and carried out the analyse in the laboratory. He prepared the materials and methods section of the manuscripts. COO draft the manuscript initially. Interpreted the results and made the concluding aspect of the work. Both authors read and approved the final manuscript.

Author details

${ }^{1}$ Department of Geology, Ebonyi State University, Abakaliki, Nigeria. ${ }^{2}$ Department of Geology, University of Nigeria, Nsukka, Nigeria.

\section{Acknowledgements}

The authors acknowledge the assistance rendered by Dr. PN Nnabo of the Department of Geology, Ebonyi State University, Abakaliki.

Competing interests

The authors declare that they have no competing interests.

Ethics approval and consent to participate

Not applicable.

\section{Publisher's Note}

Springer Nature remains neutral with regard to jurisdictional claims in published maps and institutional affiliations.

Received: 24 September 2017 Accepted: 7 December 2017

Published online: 18 December 2017 
References

1. Afolagboye OL, Talabi AO (2013) Consolidation properties of compacted lateritic soil stabilized with tyre ash. J Eng Manuf Technol 1:36-44

2. Agumanu AE (1989) The Abakaliki and Ebonyi formations subdivisions of the Albian Asu River Group in the southern Benue Trough, Nigeria. J Afr Earth Sci 9:195-207

3. Aghamelu OP, Okogbue CO (2011) Geotechnical assessment of road failures in the Abakaliki area, southeastern Nigeria. Int J Civ Environ Eng IJCEE-IJENS 11(2):12-24

4. American Society for Testing and Materials, ASTM (1982) Annual book of ASTM standards. Part 19, soil, rock and building stones. ASTM, Philadelphia

5. Anon (1975) Earth manual. US Bureau of Reclamation, Washington, DC

6. Bandara WW, Mampearachchi WK, Sampath KHSM (2017) Cement stabilized soil as a road base material for use in Sri Lankan roads. Eng J Inst Eng 01:21-29

7. Bell FG (1993) Engineering treatment of soils. Campman and Hall, London

8. Bell FG (2007) Engineering geology. Butterwotth-Heinemann, Oxford

9. Bell FG, Coulthard JM (1990) Stabilization of glacial deposits of the Middlesbrough Area with cementitious material, In: Proc 6th international congress, IAEG, Amsterdam (ed. D.G. Price), Balkema, Rotterdam, vol 3. pp 1797-807

10. Benkhelil J (1987) Cretaceous deformation, magmatism and metamorphism in the lower Benue Trough, Nigeria. Geol J 22:467-493

11. British Standard Institute, BSI (1975) Methods of testing soils for civil engineering purpose, London BS 1377

12. Cokca E (1999) Effect of fly ash on swell pressure of expansive soil. Electron J Geotech Eng Pap 9904. Oklahoma State University, Okla

13. Cratchley C, Jones GP (1965) An interpretation of the geology and gravity anomalies of the Benue Valley, Nigeria. Overseas Geol Surv Geophys Pap 1 Geol Mag 118:59-67

14. Federal Ministry of Works and Housing, Nigeria FMWH (1997) General specification for roads and bridges (revised edition), vol II. Federal Highway Department, FMWH, Lagos. pp 137-275

15. Gidigasu MD (1976) Laterite soil engineering. Elsevier, Amsterdam. pp 330-340, 359-376

16. Jenkens R, Synder RL (1976) Introduction to X-ray powder deffractometry. Willey, New York, pp 200-234

17. Joel M, Agbede IO (2010) Cement stabilization of igumale shale, lime admixture for use as flexible pavement construction material. EJGE 12:1661-1673

18. Kumar A, Singh AK (2017) Stabilization of soil using cement kiln dust. Int J Innov Res Sci Eng Technol 6(6):11631-11637

19. Muntohar AS (2002) Utilization of uncontrolled burnt rice husk ash in soil improvement. Dimensi Tekiksipil 4(2):100-105

20. Murat RC (1972) Stratigraphy and paleogeography of the Cretaceous and lower Tertiary in southern Nigeria. In: Dessauvagie TTJ, Whiteman AJ (ed) Proceeding of the conference on African geology, Ibadan. pp 251-266

21. Obiora SC, Charan SN (2011) Geochemistry of regionally metamorphosed sedimentary rocks from the lower Benue rift: implications for provenance and tectonic setting of the Benue rift sedimentary suite. S Afr J Geol 1(1):25-40

22. Okagbue CO (2007) Stabilization of clay using wood ash. J Mater Civ Eng (ASCE) 19(1):69-82

23. Okagbue $\mathrm{CO}$, Ochulor $\mathrm{OH}$ (2007) The potential of cement-stabilized coal-reject as a construction material. Eng Geol Environ 66:143-151

24. Parsons RL, Kneebone E (2005) Field performance of fly ash stabilized subgrade. Ground Improv 9:33-38

25. Sayat K, Gonconglu MC (2009) Geochemistry of mafic rocks of the Karakaya complex, Turkey; evidence for plumeinvolvement in the Palaeotethyan extensional regime during the middle and late Triassic. Int J Earth Sci 98:367-385

26. Shahiri J, Ghasemi M (2017) Utilization of soil stabilization with cement and copper slag as subgrade materials in road embankment construction. Int J Transp Eng 5(1):45-58

27. Okagbue CO, Ochulor OH (2007) The potential of cement-stabilized coal-reject as a construction material. Eng Geol Env 66:143-151

28. Wu C, Zhou B, Li Z (2007) Test of chlorides mixed with $\mathrm{CaO}, \mathrm{MgO}$ and sodium silicate for dust control and soil stabilization. J Mater Civ Eng 19(1):10-13

\section{Submit your manuscript to a SpringerOpen ${ }^{\circ}$ journal and benefit from:}

- Convenient online submission

- Rigorous peer review

- Open access: articles freely available online

- High visibility within the field

- Retaining the copyright to your article

Submit your next manuscript at $>$ springeropen.com 